\title{
Technology Entrepreneurship: Overview, Definition, and Distinctive Aspects Tony Bailetti
}

\author{
"Don't let the noise of other's opinions drown out your" \\ own inner voice. And most importantly, have the \\ courage to follow your heart and intuition. They \\ somehow already know what you truly want to become. \\ Everything else is secondary.
}

Steve Jobs (1955-2011)

Co-founder of Apple and Pixar

\begin{abstract}
Technology entrepreneurship lies at the heart of many important debates, including those around launching and growing firms, regional economic development, selecting the appropriate stakeholders to take ideas to markets, and educating managers, engineers, and scientists. Unless a generally accepted definition of technology entrepreneurship is established, however, these debates lose their focus.
\end{abstract}

The purpose of this article is to identify the themes that dominate the technology entrepreneurship literature, provide a definition of technology entrepreneurship, and identify its distinguishing aspects relative to economics, entrepreneurship, and management.

The author argues that technology entrepreneurship is an investment in a project that assembles and deploys specialized individuals and heterogeneous assets to create and capture value for the firm. What distinguishes technology entrepreneurship from other entrepreneurship types (e.g., social entrepreneurship, small business management, and self-employment) is the collaborative experimentation and production of new products, assets, and their attributes, which are intricately related to advances in scientific and technological knowledge and the firm's asset ownership rights.

\section{Introduction}

Technology entrepreneurship is a vehicle that facilitates prosperity in individuals, firms, regions, and nations. The study of technology entrepreneurship therefore, serves an important function beyond satisfying intellectual curiosity.

Previous definitions from the literature do not explore and identify: the ultimate outcome of technology entrepreneurship; the target of the ultimate outcomes; the mechanism used to deliver the ultimate outcomes; or the nature of the interdependence between technology entrepreneurship and scientific and technological advances. Moreover, a new definition should explicitly link technology entrepreneurship to the theory of the firm, entrepreneurship theory, and management theory.

In this article, the journal articles on technology entrepreneurship published since 1970 are classified into eight themes, the journals where these articles were published are examined, and the various definitions of technology entrepreneurship found in the literature are identified. A revised definition of technology entrepreneurship is proposed and its distinguishing aspects discussed. The last section provides the conclusions. 


\section{Technology Entrepreneurship: Overview, Definition, and Distinctive Aspects}

\section{Tony Bailetti}

\section{Overview of Literature Search}

The first symposium on technology entrepreneurship was held at Purdue University in October 1970 (tinyurl.com/6q8ssvd). This was the first time researchers gathered together to exchange findings and observations on this topic.

This section examines the rapid progress in the volume and breadth of research into technology entrepreneurship since that first symposium in 1970. Google Scholar (scholar.google.ca) was used to identify published journal articles containing "technology" and "entrepreneurship" or "technical" and "entrepreneurship" in the title between January 1, 1970 and December 31, 2011. The search identified 93 articles published in 62 journals, which were then classified and examined more closely, as described in the sections that follow.

Table 1 organizes the 93 journal articles on technology entrepreneurship into eight themes and five time periods: 1970-1979, 1980-1989, 1990-1999, 2000-2009, and 2010-2011. The duration of the first four periods is ten years, while that of the last period is only two years. Table 1 suggests that:

1. Over the first four time periods, the number of articles published in each period has generally more than doubled the number of articles published in the previous period.

2. The number of articles published in the last 12 years accounts for $66 \%$ of the number of articles published over the last four decades.

Table 1. Breakdown of the number of journal articles with "technology" and "entrepreneurship" or "technical" and "entrepreneurship" in the title, by theme, and period

\begin{tabular}{|c|c|c|c|c|c|c|c|c|}
\hline & \multirow[b]{2}{*}{ Themes } & \multicolumn{6}{|c|}{ Number of Journal Articles } & \multirow[b]{2}{*}{$\begin{array}{l}\% \text { of total } \\
1970-2011\end{array}$} \\
\hline & & $\begin{array}{l}1970- \\
1979\end{array}$ & $\begin{array}{l}1980- \\
1989\end{array}$ & $\begin{array}{l}1990- \\
1999\end{array}$ & $\begin{array}{l}2000- \\
2009\end{array}$ & $\begin{array}{l}2010- \\
2011\end{array}$ & $\begin{array}{c}\text { Total } \\
1970-2011\end{array}$ & \\
\hline 1 & $\begin{array}{l}\text { External factors that influence formation of } \\
\text { technology firms }\end{array}$ & 0 & 2 & 7 & 23 & 10 & 42 & $45 \%$ \\
\hline 2 & $\begin{array}{l}\text { How, why and when technology } \\
\text { entrepreneurship affects the socio-economic } \\
\text { development of a region }\end{array}$ & 0 & 3 & 3 & 7 & 1 & 14 & $15 \%$ \\
\hline 3 & $\begin{array}{l}\text { Approaches used by small technology firms to } \\
\text { generate revenue and reduce costs }\end{array}$ & 0 & 1 & 3 & 6 & 2 & 12 & $13 \%$ \\
\hline 4 & $\begin{array}{l}\text { Internal practices used to operate and transform } \\
\text { small technology firms }\end{array}$ & 1 & 0 & 5 & 4 & 0 & 10 & $11 \%$ \\
\hline 5 & $\begin{array}{l}\text { Interdependence between technology path and } \\
\text { small technology firm formation and growth }\end{array}$ & 0 & 2 & 3 & 1 & 0 & 6 & $7 \%$ \\
\hline 6 & Overview of technology entrepreneurship & 1 & 0 & 0 & 2 & 1 & 4 & $4 \%$ \\
\hline 7 & $\begin{array}{l}\text { Corporate entrepreneurship function in mid- } \\
\text { sized and large firms }\end{array}$ & 0 & 0 & 1 & 2 & 1 & 4 & $4 \%$ \\
\hline \multirow[t]{2}{*}{8} & Contributions to other fields & 0 & 0 & 0 & 1 & 0 & 1 & $1 \%$ \\
\hline & Number of articles & 2 & 8 & 22 & 46 & 15 & 93 & $100 \%$ \\
\hline
\end{tabular}




\section{Technology Entrepreneurship: Overview, Definition, and Distinctive Aspects}

\section{Tony Bailetti}

\section{Themes}

The information shown in Table 1 suggests that:

1. The technology entrepreneurship literature is dominated by a theme that focuses on identifying the antecedents of technology firm formation.

2. Another theme addresses the consequences of technology entrepreneurship. It focuses on how, why, and when technology entrepreneurship affects the socioeconomic development of a region.

3. Two other themes address what occurs inside small firms engaged in technology entrepreneurship and another theme focuses on the interdependence between small-firm initiatives and the external infrastructure that contributes to science and technology advances.

4. The technology entrepreneurship literature has focused more on small technology firms than mid-sized and large firms.

5. Scholarly work on technology entrepreneurship has not contributed substantially to other fields such as economics, entrepreneurship, or management.

The dominant theme (Theme 1) accounts for $45 \%$ of the number of articles on technology entrepreneurship published during the past four decades. It focuses on external factors that influence the formation of technology firms. This theme describes the systems that support the foundation of new technology firms. The articles cover topics on: characteristics of technology entrepreneurs; external events that create technology opportunities for technology entrepreneurs; university and business incubators; firm spinoff and technology transfer mechanisms; government programs that support technology entrepreneurship; funding of new technology firms; entrepreneurship education; and commercialization capability.

Theme 2 focuses on how technology entrepreneurship affects regional development. The how, why, and when technology entrepreneurship affects the socio-economic development of a region is addressed in articles on the relationship between technology entrepreneurship and the regional economies of developed countries, de- veloping countries, and countries in transition; technology transfer mechanisms that enable entrepreneurship in developing countries; technology as a driver of entrepreneurship in non-technology sectors; technology entrepreneurship and women's rights; and the effect of technology entrepreneurship on government policy.

Two additional themes (Themes 3 and 4) address what occurs inside small firms (i.e., those with less than 50 employees). These themes account for $24 \%$ of the 93 articles and examine approaches for revenue generation, cost reduction, operations, and business transformation.

Theme 5, which accounts for $7 \%$ of the articles reviewed, focuses on the interdependence between technology initiatives carried out by small firms and external advances in science and technology.

Corporate entrepreneurship functioning in mid-sized and large firms (Theme 7) is the only theme that does not focus on small technology firms or technology firm formation. It accounts for only $4 \%$ of the total number of articles on technology entrepreneurship.

The results suggest that scholarly work on technology entrepreneurship has not contributed significantly to other fields (Theme 8). Only one of the 93 articles focuses on a contribution made to another field despite the relationship between entrepreneurship and the wider environment (Busenitz et al., 2003; tinyurl.com/ 7ar6vqy). We can surmise that the reason for this is that the number of scholars contributing to the field of technology entrepreneurship is not large.

Figure 1 organizes seven of the eight themes shown in Table 1 into three clusters. The overview theme (Theme 6 ) is not shown in Figure 1. The first cluster includes the four themes anchored around technology venture formation. This cluster includes themes that focus on the antecedents (Theme 1) and consequences (Themes 2 and 8) of technology venture formation as well as its interdependence with change in technology (Theme 5).

The second cluster includes the two themes that focus on small technology firms (Themes 3 and 4) and the third cluster includes the theme that focuses on midsized and large firms (Theme 7). 


\title{
Technology Entrepreneurship: Overview, Definition, and Distinctive Aspects
}

Tony Bailetti

\author{
Technology Change \\ 5. Interdependence

\section{External factors Technology Venture Formation} \\ 2. Region's development \\ 8. Contribution to another field
}

\section{Small Technology Firms}

3. Approaches to generate revenue and reduce costs

4. Operations and transformation of small firms

\section{Mid-sized and Large Firms}

7. Corporate entrepreneurship

Figure 1. Seven themes of technology entrepreneurship organized into three clusters

\section{Journals: Domains and Rankings}

To assess the quality of the journals where the 93 articles were published, criteria to identify a list of "good" journals in technology innovation or entrepreneurship domains were first defined and then the journals that met the criteria were identified. To be part of the list of "good" journals, a journal had to be: i) rated A or B by Franke and Schreier (2008; tinyurl.com/7ma9ldq); ii) included in the Financial Times' Top 45 Journals list (Financial Times, 2010; tinyurl.com/7f86zee); and iii) used by Linton in his comparison between technology innovation management journals and those journals that appear in the list of the Financial Times' Top 45 Journals. (2011; tinyurl.com/7u7bglg).

The remainder of this section summarizes our key findings in relation to journal domains and rankings.

\section{The majority of technology entrepreneurship articles are published in journals not considered contributors to technology innovation or entrepreneurship}

Of the 62 journals that published the 93 articles reviewed here, only 18 (29\%) were considered to be journals that contribute to technology innovation management or entrepreneurship by Franke and Schreier (2008; tinyurl.com/7ma9ldq).

2. Two to seven journals in technology innovation and entrepreneurship met the criteria for "good" journals
Only two of the 62 journals that published technology entrepreneurship articles met the criteria for a "good" journal: Entrepreneurship Theory and Practice and Journal of Business Venturing.

To include more journals in the list of "good journals", we dropped the requirement that the journal be included in the Financial Times' Top 45 Journals list. When we relaxed the criteria for a "good" journal, seven journals were included in the list of "good" journals. These are: Research Policy (5), R\&D Management (4), Journal of Business Venturing (3), International Journal of Technology Management (2), IEEE Transactions on Engineering Management (1), Entrepreneurship Theory and Practice (1), and Journal of Product Innovation Management (1). The numbers in brackets refer to the number of articles in our sample published by each journal.

\section{Eighteen percent of the 93 articles in Table 1 were pub-} lished in seven "good" journals

We found that 17 of the 93 articles in Table 1 (18\%) were published in the seven journals that met the relaxed criteria for a good journal. Four of the 93 articles (4\%) in Table 1 were published in the two journals that met our original criteria for a good journal.

These findings suggest that technology entrepreneurship is still a relatively new field of study. The number of scholars publishing articles about technology entrepreneurship in top journals remains quite small. 


\section{Technology Entrepreneurship: Overview, Definition, and Distinctive Aspects}

\section{Tony Bailetti}

\section{Existing Definitions}

Six definitions of technology entrepreneurship were found in the 93 articles reviewed:

1. Organization, management, and risk bearing of a technology based business (Nicholas and Armstrong; 2003; tinyurl.com/7tv9pdq)

2. Solutions in search of problems (Venkataraman and Sarasvathy, 2000; tinyurl.com/7ufaes4)

3. Establishment of a new technology venture (JonesEvans, 1995; tinyurl.com/7vfgww7)

4. Ways in which entrepreneurs draw on resources and structures to exploit emerging technology opportunities (Liu et al., 2005; tinyurl.com/6mgecu8)

5. Joint efforts to interpret ambiguous data, joint understanding to sustain technology efforts, and persistent, coordinated endeavor to accomplish technological change (Jelinek, 1996; tinyurl.com/783jc4n)

6. An agency that is distributed across different kinds of actors, each of which becomes involved with a technology and, in the process, generates inputs that result in the transformation of an emerging technological path (Garud and Karnøe, 2003; tinyurl.com/6pdm8bn)

The definitions found in the literature suggest that technology entrepreneurship is about: i) operating small businesses owned by engineers or scientists; ii) finding problems or applications for a particular technology; iii) launching new ventures, introducing new applications, or exploiting opportunities that rely on scientific and technical knowledge; and iv) working with others to produce technology change.

\section{Defining Technology Entrepreneurship}

The field of technology entrepreneurship is in its infancy when compared to other fields such as economics, entrepreneurship, and management. However, we are at a point where we can leverage the insights contributed by previous work to create a clearer working definition of technology entrepreneurship.

This article proposes a general definition that identifies the distinctive characteristics of technology entrepreneurship and describes its links with the fields of eco- nomics, entrepreneurship, and management. The proposed formal definition of technology entrepreneurship should prove valuable in adding to our understanding of how entrepreneurship functions in a firm that invests in projects that are interdependent with advances in science and technology.

The following definition of technology entrepreneurship is proposed:

Technology entrepreneurship is an investment in a project that assembles and deploys specialized individuals and heterogeneous assets that are intricately related to advances in scientific and technological knowledge for the purpose of creating and capturing value for a firm.

The proposed definition of technology entrepreneurship is based on four elements:

1. Ultimate outcomes. Value creation and capture are identified as two outcomes of technology entrepreneurship because the sources that create value and the sources that capture value may not be the same over the long run.

2. Target of the ultimate outcomes. The firm is identified as the target organization for which value is created and captured.

3. Mechanism used to deliver the ultimate outcomes. Investment in a project is the mechanism mobilized to create and capture value. A project is a stock of resources (i.e., specialized individuals and heterogeneous assets) committed to deliver the two ultimate outcome types for a period of time.

4. Interdependence of this mechanism with scientific and technological advances. The individuals involved in a project influence and are influenced by advances in relevant scientific and technology knowledge. The project exploits or explores scientific and technology knowledge. External and internal individuals and organizations co-produce the project's outputs.

When compared to the definitions identified in the previous section, the definition proposed above:

1. Emphasizes that technology entrepreneurship is about creating and capturing value for the firm through projects that combine specialists and assets to produce and adopt technology 


\section{Technology Entrepreneurship: Overview, Definition, and Distinctive Aspects}

\section{Tony Bailetti}

2. Highlights the collaborative experimentation and production of new products, new assets, and their attributes, which are intricately linked to scientific and technology advances and the firm's asset ownership rights

3. Specifies that technology entrepreneurship may entail projects that search for problems or applications for a particular technology, launch new ventures, introduce new applications, and exploit opportunities that rely on scientific and technical knowledge provided that their ultimate outcome is to create and capture value for the firm

4. Clarifies that technology entrepreneurship is not about the general management practices used to operate small businesses owned by engineers or scientists or just about small businesses

\section{Differentiating Aspects}

There are at least five differentiating aspects of technology entrepreneurship in the definition proposed above.

\section{How technology entrepreneurship differentiates from other entrepreneurship types \\ The interdependence between scientific and technolo- gical change, as well as the selection and development of new products, assets, and their attributes, differenti- ate technological entrepreneurship from other entre- preneurship types.}

Technology entrepreneurship has more to do with collaborative production based on a shared vision of future changes in technology. The existing entrepreneurship literature, however, describes an entrepreneur as: i) "an alert individual discovering an existing opportunity" (Shane, 2003: tinyurl.com/7ck6h95; Shane and Venkataraman, 2000: tinyurl.com/7lgvwyw); ii) "an innovative individual who shakes the economy out of its previous equilibrium" (Schumpeter, 1939; tinyurl.com/7dtghyp); iii) "an experienced individual making judgments about an unknowable future" (Foss and Klein, 2005; tinyurl.com/7xd3xd8); iv) "an individual who believes she has lower information costs than others" (Casson and Wadeson, 2007; tinyurl.com/869g49o); vi) "an individual with certain personality traits" (Hood and Young, 1993; tinyurl.com/7nj82e3); and vi) "a charismatic leader" (Witt, 1998; tinyurl.com/7wwqtug).

A shared vision of change in technology influences why, when, and how a firm creates and captures value.
Technology change can be represented in various ways. Therefore, it is important to develop a shared view of change in technology.

\section{Eliminating the existing biases in the entrepreneur- ship literature}

The proposed definition eliminates three biases of entrepreneurship research: i) concentration on new firm formation; ii) focus on individual entrepreneurs; and iii) over-attention to opportunity discovery (Foss, 2011; tinyurl.com/6wamh2j).

Technology entrepreneurship, as defined above, applies equally well to newly formed or established firms as well as small or large firms. Established and large firms can engage in technology entrepreneurship just as well as startups do.

Technology entrepreneurship is about collaborative production decisions, not about a single individual making or delegating decisions. The firm's top management team jointly decides to invest in a project and a team of specialized individuals who create and capture value for the firm. The specialized individuals and assets can be held by a single entrepreneur-manager or can be distributed.

Technology entrepreneurship involves specialized human resources, tapping into their skills and ability to collaboratively explore and exploit scientific and technological change to benefit the firm. Technology entrepreneurship is best understood therefore, as a joint-production phenomenon that draws from a team of specialized individuals from multiple domains, some or all of whom become embedded in the technology path they try to shape in real time (Garud and Karnøe, 2003; tinyurl.com/6pdm8bn). Technology entrepreneurship is not about a single individual or the inventions they introduce. It is about managing joint exploration and exploitation, where each individual has roles and responsibilities in collaboratively and cooperatively moving forward toward accomplishing shared goals (Lindenberg and Foss, 2011; tinyurl.com/6oh6yuo). Technology entrepreneurship is about investing in and executing the firms' projects, not just recognizing technology or market opportunities.

\section{A more theoretically rigorous and practical definition}

Considering technology entrepreneurship as an investment in a project rather than a subjective opportunity allows it to be assessed in more theoretically rigorous and practical terms. It transforms the subjective view of 


\section{Technology Entrepreneurship: Overview, Definition, and Distinctive Aspects}

\section{Tony Bailetti}

technology or market ideas to the objective reality of project definition, financing, and execution. The proposed definition links technology entrepreneurship to an amount of money (i.e., investment in the project). Ideas are mere parlour games until money is part of a project (Rothbard, 1985; tinyurl.com/75f2boc).

\section{Linking technology entrepreneurship to the theory of sustainable competitive advantage}

Technology entrepreneurship and the resource-based view of sustainable competitive advantage (tinyurl.com/ 753qbxo) are interdependent because they are both concerned with how to create and capture value. Both pay explicit attention to how resources that embody technology and scientific advances create and capture value. While technology entrepreneurship applies to any firm with projects that rely on advances of science and technology, the resource-based view applies to those few firms that are continuously successful.

The resource-based theory of sustainable competitive advantage is the dominant view in strategic management. It links firm performance to firm resources and includes concepts such as capabilities, dynamic capabilities, and core competences. Scholars working in this field seek to clarify how a firm can create and capture more value than its competitors on a sustained basis (Peteraf and Barney, 2003; tinyurl.com/8x8qfmt).

For value-creation activities to endure over the long term, the amount customers pay the firm must be: i) greater than the firm's cost of production and ii) a function of the difference between the satisfaction customers receive from consuming the firm's goods or services and the satisfaction customers would receive from consuming the closest alternative goods or services. For the firm to capture the value it creates, "use value" (i.e., utility of consuming a good) and "exchange value" (i.e., price paid for the good) should be similar. If use value is high and exchange value is low, other agents (e.g., intermediaries, competitors) are capturing the value created for customers (Lepak et al., 2007; tinyurl.com/6rmbk6g).

\section{Linking technology entrepreneurship to the theory of the firm}

The technology entrepreneurship domain and the theory of the firm are interdependent through the specialized individuals and heterogeneous assets committed to a project for the purpose of creating and retaining value for the firm.
The specialized individuals and heterogeneous assets in the project's stock of resources can be considered reference points in the theory of the firm. The theory of the firm aims to explain why firms exist, what determines their boundaries, what determines their structure, and what drives their different actions and performances.

The proposed definition emphasizes the importance of technology entrepreneurship in enabling specialized individuals to develop combinations of assets and their attributes in order to create and capture value for the firm. An "asset" refers to an economic resource that is owned or controlled by the firm and is used to create and capture value for the firm. An asset represents value ownership that the firm may convert into cash. An asset can be thought of as a bundle of attributes defined by their characteristics, functions, and potential uses. The term "heterogeneous assets" refers to a set of assets that lack uniformity in composition or character.

The firm's owners and employees have no way of knowing or predicting the relevant attributes of all the assets. Asset attributes need to be discovered. Technological entrepreneurship identifies, selects, and develops new attributes for the purpose of creating and capturing value for the firm.

Technology entrepreneurship requires a firm for two reasons. First, the firm must control the assets that specialized individuals use to experiment with new combinations of assets and their attributes. Second, the requisite joint investment and production decisions cannot be purchased on the market. The reasons that technology entrepreneurship needs a firm are similar to the reasons why an entrepreneur needs a firm described by Foss, Klein, and Bylund (2011; tinyurl.com/8xfhvlg).

\section{Conclusion}

Over the last four decades, technology entrepreneurship has become an increasingly important global phenomenon. It is perceived as necessary for growth, differentiation, and competitive advantage at the firm, regional, and national levels. Technology entrepreneurship appeals mainly to leaders and top management teams of small and large firms who use technology to create, deliver, and capture value for their stakeholders. Technology entrepreneurship also appeals to person- 


\section{Technology Entrepreneurship: Overview, Definition, and Distinctive Aspects}

\section{Tony Bailetti}

nel of regional economic development agencies that attract investments in productive technologies and talent to a particular geography.

The primary function of technology entrepreneurship is to assemble a combination of specialized individuals and heterogeneous assets in order to create and capture value for the firm through collaborative exploration and experimentation. The combination, some of the assets, or the assets' attributes may be unique and novel. The initial combination may change over time.

In this article, the literature on technology entrepreneurship was classified into eight themes. The literature search revealed that most of the articles on technology entrepreneurship appeared in journals not considered to be in the technology innovation/entrepreneurship domain.

The article offered a definition for technology entrepreneurship. A better definition of technology entrepreneurship can help improve its performance, increase its relevance, and establish it as a legitimate domain of inquiry in its own right. This definition needs to identify and incorporate the various distinctive aspects of technology entrepreneurship and its links to the existing domains of economics, entrepreneurship, and management. The definition, including the corresponding features and links, requires particular attention from scholars and practitioners.

The aspects of technology entrepreneurship to which we need to pay particular attention are identified. These aspects are: i) the interdependence between scientific and technological change and the selection and development of new combinations, assets, and asset attributes; ii) biases in the existing entrepreneurship literature; iii) conceptualization of technology entrepreneurship as an investment in a project, rather than opportunity recognition or venture formation; and iv) links among technology entrepreneurship, the theory of sustainable competitive advantage, and the theory of the firm.

\section{About the Author}

Tony Bailetti is an Associate Professor in the Sprott School of Business and the Department of Systems and Computer Engineering at Carleton University, Ottawa, Canada. Professor Bailetti is the Director of Carleton University's Technology Innovation Management program. His research, teaching, and community contributions support technology entrepreneurship, regional economic development, and international co-innovation.

Citation: Bailetti, T. 2012. Technology Entrepreneurship: Overview, Definition, and Distinctive Aspects. Technology

(cc) BY 